\title{
An Algorithm for the Retrieval of Aerosol Optical Depth from Geostationary Satellite Data in Thailand
}

\author{
Itsara Masiri", Serm Janjai, and Treenuch Jantarach \\ Laboratory of Tropical Atmospheric Physics, Department of Physics, Faculty of Science, \\ Silpakorn University, Nakhon Pathom, Thailand, 73000
}

\begin{abstract}
An algorithm was developed to estimate aerosol optical depth (AOD) from geostationary satellite data. The $6 \mathrm{~S}$ radiative transfer computer code was employed to generate a look-up table (LUT) which incorporates several combinations of satellite-derived variables including earthatmospheric reflectivity, atmospheric reflectivity and surface albedo. The parameterization of the satellite-derived atmospheric reflectivity accounted for the scattering of solar radiation by clouds, absorption of solar radiation by water vapour, ozone and gases and solar radiation depletion by aerosols. The digital data of the MTSAT-1R satellite were used as the main input of the algorithm. For the validation, the values of AOD derived from this algorithm were compared with those obtained from four sites of Aerosol Robotic Network (AERONET) in Thailand, and a reasonable agreement was found.
\end{abstract}

\section{Introduction}

Climatology of aerosol properties is an important data for supporting the atmospheric research and climate change studies (Breon et al., 2002; Hansen et al., 2000; Zhang et al., 1997; Charson et al., 1992). Because aerosols are known as an important agent of radiative forcing and climatic disturbance (Nakajima et al., 2003; Dubovik et al., 2002), it is therefore vital to characterize the aerosol optical properties. At regional scale, the amount of aerosols varies as a result of local temperatures, precipitations, wind profile and topography of the region (Xie and Xia, 2008; Li et al., 2007; Lohmann and Feichter, 2005). Over high polluted areas, aerosols can diminish solar radiation by more than $20 \%$ (Nunez, 1993). In addition, it is evident that lifetime of aerosols in the atmosphere may range from days to several weeks depending on weather conditions. In South East Asia, early studies reported that most aerosols in the regions are originated from local pollutants, biomass burning and forest fire events (Janjai et al., 2009; Hoyningen-Huene et al., 1999).

Aerosol optical properties can be measured by using sunphotometers. However, it is costly to provide such a dense network of measurements over a large area. Due to a lack of comprehensive measurements of aerosol optical properties on global scale, satellite-based aerosol retrievals from Moderate Resolution Imaging Spectroradiometer (MODIS), Multiangle Imaging Spectroradiometer (MISR), the Polarization and Directionality of the Earth's Reflectances (POLDER) were developed to provide aerosol optical properties over the globe (Deuzé et al., 2000; Tanré et al., 1997; Kaufman et al, 1997).

However, aerosol information form these satellites has relatively short historical records. In addition, such information is available only once or twice a day. Geostationary satellites have longer period of records and the imagery data from these satellites are available every hour. From 
these advantages, we developed in this work an algorithm for retrieving aerosol optical depth (AOD) from geostationary satellite data. The algorithm was based on a look-up table (LUT) generated from the $6 \mathrm{~S}$ radiative transfer computer code. This algorithm was also validated against AOD measurement data of AERONET (Aerosol Robotic Network) in Thailand.

\section{Methodology}

\subsection{Processing of satellite data}

The visible images collected at near local noon time from MTSAT-1R (September, 2006 December, 2010) satellites were used as the main input of the proposed aerosol retrieval algorithm. The images in the satellite projection were transformed into the cylindrical projection which represents the linear distance associated with the geocoordinate system. The images in the cylindrical scene were then navigated using a feature of the coastlines as a reference point. The navigated image consists of a matrix of $500 \times 800$ pixels covering the entire areas of Thailand (Fig. 1). Each pixel of these satellite images contains 8-bit digital counts which associate to the values of gray levels from 0 to 255 . The values were converted into earth-atmospheric reflectivity $\left(\rho_{E A}\right)$ using a calibration table provided by Japanese Meteorological Agency (JMA). With the values of $\rho_{E A}$ and solar radiation incident on the top of the atmosphere $\left(I_{e x t}\right)$, solar radiation reflected by the earth-atmospheric system at the satellite position $\left(I_{\text {sat }}\right)$ can be calculated.

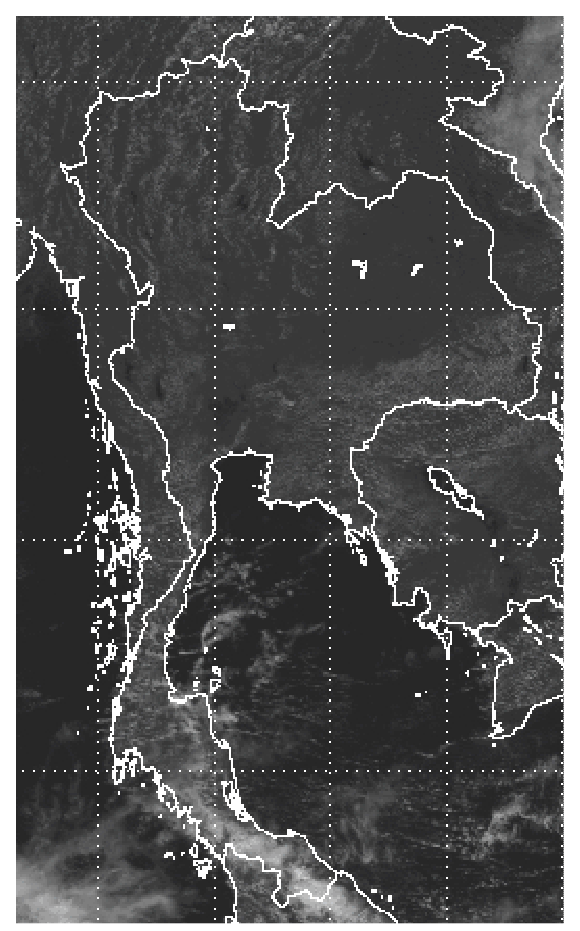

Fig. 1: Satellite image in cylindrical projection.

\subsection{Development of the look-up table algorithm}


In this study, an algorithm based on a look-up table (LUT) was developed for the retrievals of aerosol optical depth (AOD) from MTSAT-1R satellite data. The LUT was generated from the $6 \mathrm{~S}$ radiative transfer computer code (Vermote et al., 1997). The 6S - Second Simulation of a Satellite Signal in the Solar Spectrum - is a radiative transfer code used for the simulation of the signals expected to be received by various satellites. Inputs of the $6 \mathrm{~S}$ incorporate several factors including geometrical condition (e.g. satellite and target positions), spectral bands, surface reflectance, atmospheric profiles, aerosol models and environmental function. Based on the radiative transfer theory, the $6 \mathrm{~S}$ can estimate upwelling-irradiance received by satellites $\left(I_{\text {sat }}\right)$, if all necessary input data are given to this code (Fig 2).

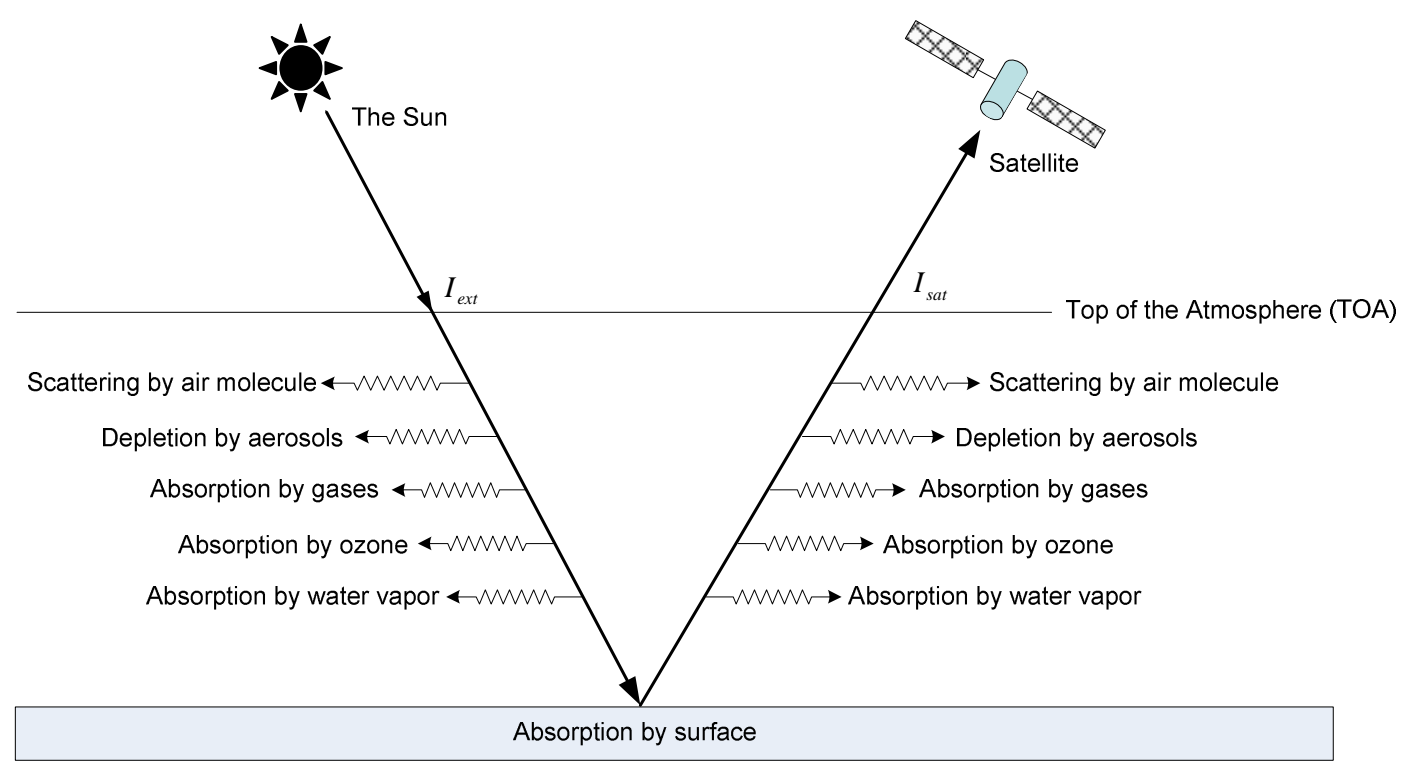

Fig. 2: Schematic diagram of solar radiation depletion by various atmospheric constituents and solar radiation received by satellite $\left(I_{\text {sat }}\right)$.

In our case, the input parameters of the $6 \mathrm{~S}$ were obtained as follows. The absorption of solar radiation by ozone was calculated from the total column ozone obtained from OMI/AURA satellite. The absorption by water vapor was computed from precipitable water derived from ambient temperature and relative humidity employing a formula developed by Janjai et al. (2005). Atmospheric reflectivity $\left(\rho_{A}\right)$ was derived from the method proposed by Janjai et al., (2005). This method was originally developed for estimating solar radiation for Thailand. The method is based on the physical model relating broadband to satellite-derived (narrow-band) atmospheric reflectivity. The model considers the attenuation processes caused by various atmospheric constituents including absorption due to ozone, water vapor and gases and scattering due to aerosols. Surface albedo used for the $6 \mathrm{~S}$ was computed by using the technique of Janjai et al., (2006). It was estimated on a monthly basis from the MTSAT-IR satellite images collected at $12.30 \mathrm{~h}$ local time. According to the technique, for each month, gray levels of the images were examined and pixels with the lowest value of gray levels were selected to construct a cloud-free composite image for that month. All gray levels of the cloud-free composite image were converted into cloud-free earth-atmospheric albedo. A statistical equation relating cloud-free 
earth-atmospheric albedo and surface albedo was created by using the $6 \mathrm{~S}$. Then equation was used to compute surface albedo over the country.

Solar zenith angle required by the algorithm was determined from the position of the satellite pixel and time. Only the unknown input parameter is AOD. However, in our case, the output parameter $I_{s a t}$ is known. It was obtained from satellite data. In principle, from these input and output parameters, we can solve for the value of AOD.

Due to the complexity for solving directly AOD from $6 \mathrm{~S}$, we used $6 \mathrm{~S}$ to calculate a set of the values of $I_{\text {sat }}$ from several combinations of the values of the input parameters and stored all of these values of input and output parameters in a table called a look-up table (LUT). Then this LUT was used to search for the value of AOD which gave the value of $I_{\text {sat }}$ equal or close to that obtained from satellite data (Fig 3).

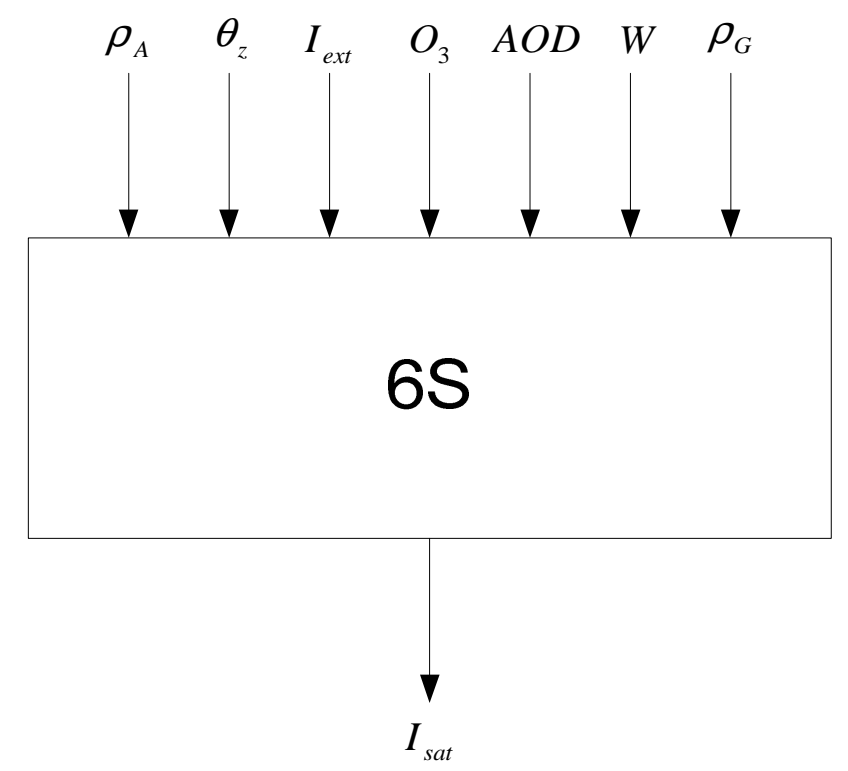

Fig. 3: Schematic diagram showing input and output of $6 \mathrm{~S}\left(\rho_{A}=\right.$ atmospheric reflectivity, $\rho_{G}=$ surface albedo, $I_{e x t}=$ extraterrestrial solar radiation, $A O D=$ aerosol optical depth, $\theta_{z}=$ solar zenith angle, $O_{3}=$ total column ozone, $W=$ precipitable water).

\subsection{Cloud screening method}

As the proposed algorithm is valid for a clear sky condition, only clear sky pixels from satellite data can be used in the algorithm. Therefore, it is necessary to identify the clear sky pixels.

Thailand consists of the sea surface in the Gulf of Thailand and Andaman Sea and the land surface. The sea surface has low reflectivity whereas the land surface has higher reflectivity. In the case of clear sky over the country, the statistical distribution of the reflectivity will show two distinct peaks, the first peak for the sea surface and the second for the land surface (Fig 4). From the maximum limit of the second peaks, a clear sky threshold can be defined. This method was also verified by using the cloud images taken at Chiang Mai $\left(18.78^{\circ} \mathrm{N}, 98.97^{\circ} \mathrm{E}\right)$, 
Ubonratchathani $\left(15.25^{\circ} \mathrm{N}, 104.87^{\circ} \mathrm{E}\right)$, Nakhon Pathom $\left(13.82^{\circ} \mathrm{N}, 100.04^{\circ} \mathrm{E}\right)$ and Songkhla $\left(7.18^{\circ} \mathrm{N}, 100.60^{\circ} \mathrm{E}\right)$. Then this threshold was used to identify the clear pixels.

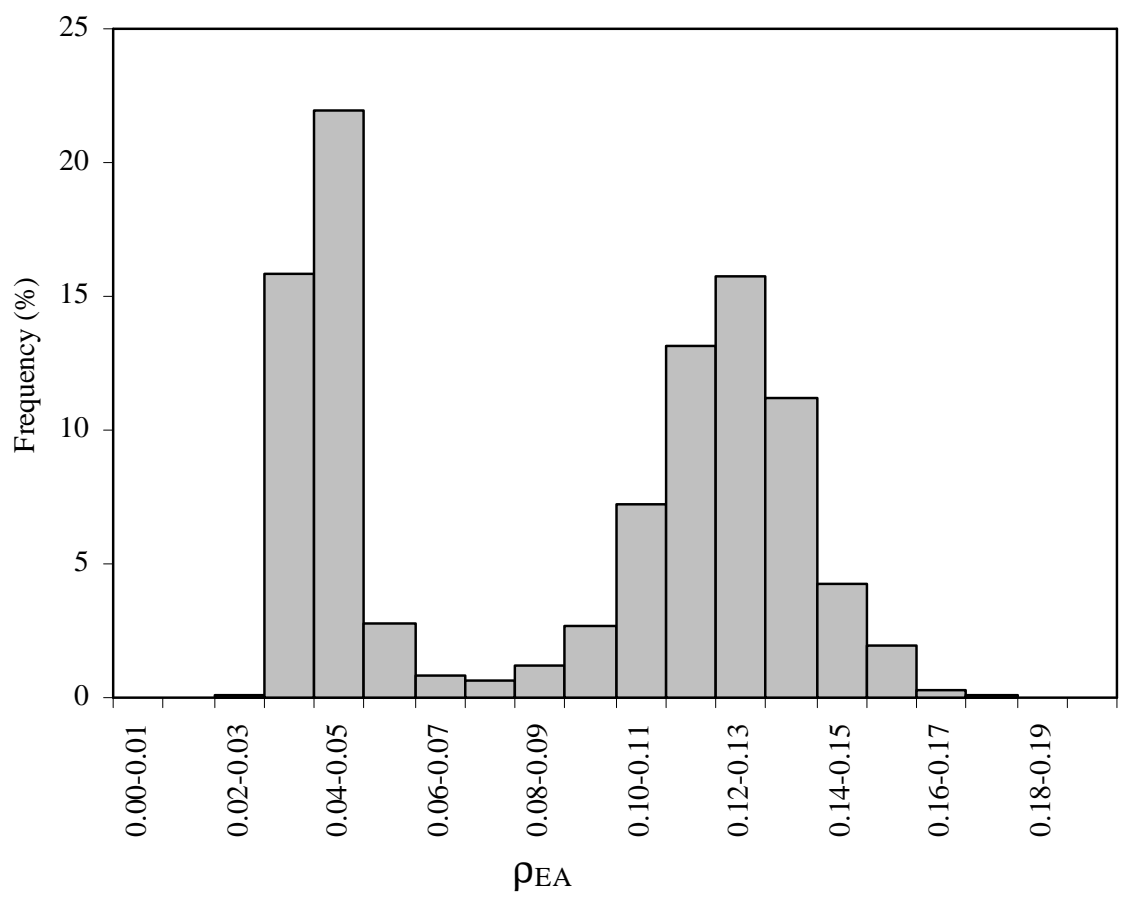

Fig. 4: Frequency distribution of the cloudless sky reflectivity $\left(\rho_{E A}\right)$ derived from the clear sky satellite images.

\subsection{Validation of the algorithm}

To validate the algorithm, it was used to retrieve the aerosol optical depth at four sites of Aerosol Robotic Network (AERONET) in Thailand, namely Chiang Mai $\left(18.78{ }^{\circ} \mathrm{N}, 98.98^{\circ} \mathrm{E}\right)$ in the North, Ubon Ratchathani $\left(15.25^{\circ} \mathrm{N}, 104.87^{\circ} \mathrm{E}\right)$ in the Northeast, Nakhon Pathom $\left(13.82{ }^{\circ} \mathrm{N}\right.$, $\left.100.04^{\circ} \mathrm{E}\right)$ in the Center, and Songkhla $\left(7.2^{\circ} \mathrm{N}, 100.60^{\circ} \mathrm{E}\right)$ in the South. For each site, all input data of the algorithm were prepared and used in the algorithm to obtain values aerosol optical depth at the site for the clear sky period at local noon time (Fig. 5). For each month, these values were averaged over the period of that month.

For the measurement at each site, the CIMEL sunphotometer was programmed to measure direct and sky solar irradiances at the wavelengths of 340,380, 440, 500, 675, 870, 940 and 1,020 nm. The sunphotometers at 4 sites belong to our laboratory and they were maintained by our staffs. The quality control and data conversions were performed at the central processing facility of AERONET at NASA (Dubovik et al., 2000). The values aerosol optical depth at $500 \mathrm{~nm}$ supplied by AERONET were averaged over the same period as that of aerosol optical depth from the algorithm. Finally, the values of aerosol optical depth from the measurements were compared with those from the algorithm and the results are presented in the next section. The periods of the data used for the comparison are shown in Table 1. 


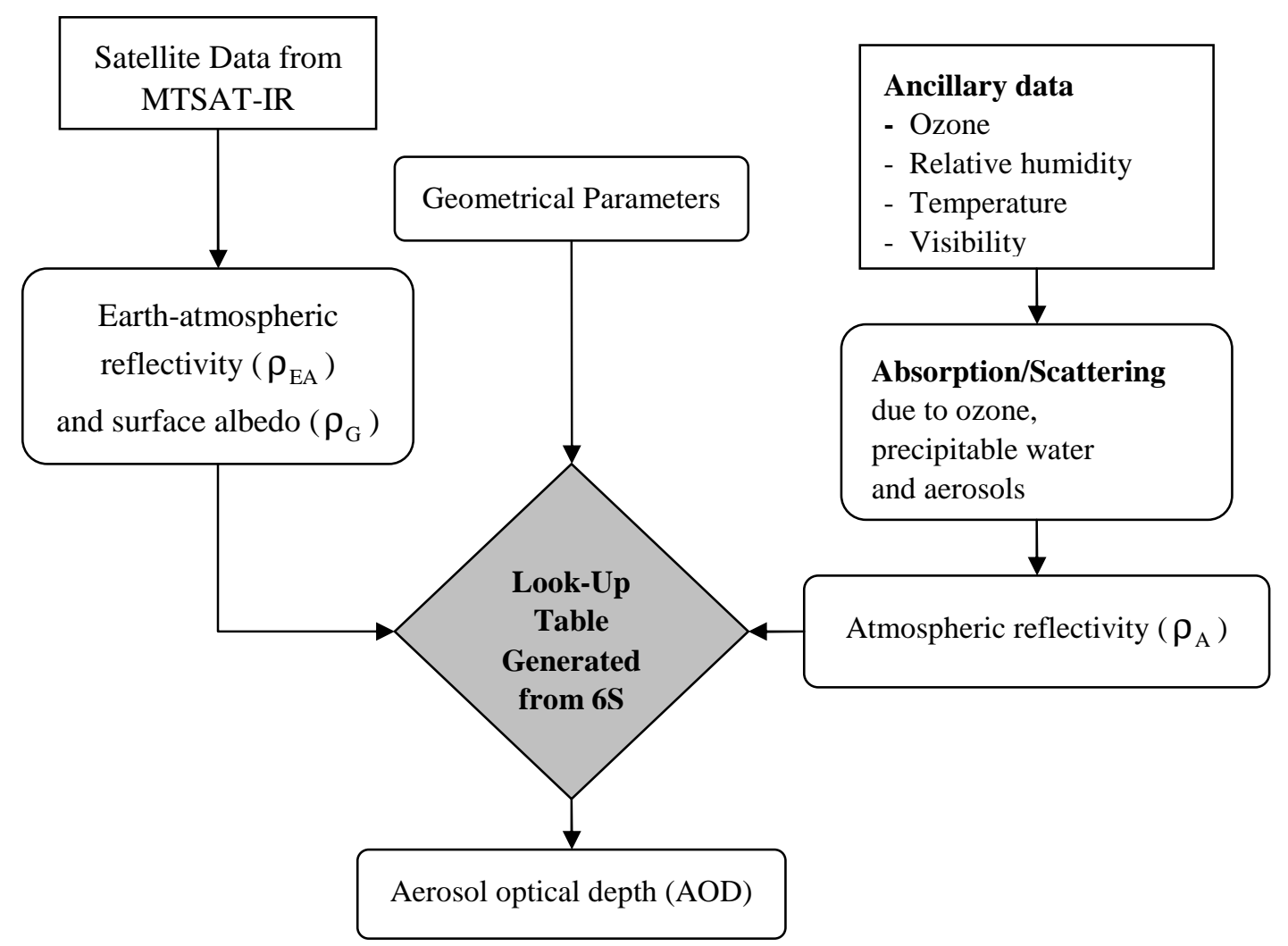

Fig. 5: Schematic diagram of the algorithm used to estimate aerosol optical depth.

Table 1: Periods of data used for the comparison of aerosol optical depth obtained from the algorithm and the measurements.

\begin{tabular}{|l|l|}
\hline Site & Period \\
\hline Chiang Mai & September 2006 - December 2008 \\
\hline Ubon Ratchathani & October 2009 - December 2010 \\
\hline Nakhon Pathom & August 2006 - December 2008 \\
\hline Songkhla & January 2007 - December 2008 \\
\hline
\end{tabular}

\section{Results and discussion}

Fig. 6 show the discrepancy in terms of mean bias difference (MBD) and root mean square difference (RMSD) between aerosol optical depth values retrieved from satellite data and those obtained from the measurements.

It was observed that MBD values for Chiang Mai, Ubon Ratchathani and Nakhon Pathom varied with in $\pm 9 \%$ interval. The highest MBD value was observed for Songkhla $\quad(-18 \%)$. The values of RMSD for Chiang Mai, Nakhon Pathom and Songkhla are in the range of 23\%-33\%. The 
highest RMSD value (48.6\%) was observed for Ubon Ratchathani. Overall, the comparisons yields root mean square difference of $0.13(34.3 \%)$ and mean bias difference of $-0.01(-2.3 \%)$, (Fig 7). The discrepancy between AOD values retrieved from satellite data and those obtained from the measurements may be explained as follows.

The aerosol models used in the LUT construction process were fixed for urban, continental and maritime environments. However, the aerosol at the four sites may not correspond to the aerosol types used to generate the LUT. This mismatch of the aerosol properties is likely to cause the errors of the AOD retrieved by using the LUT.

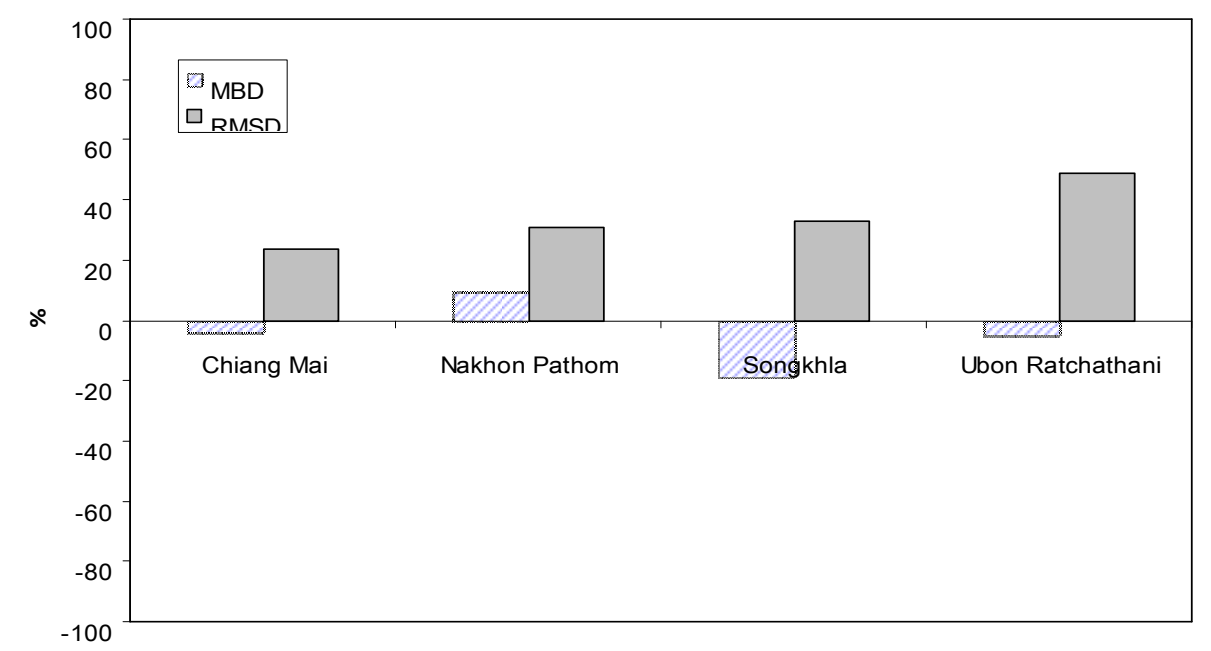

Fig. 6: Comparison between the aerosol optical depth derived from satellite data and the AERONET measurements at Chiang Mai, Ubon Ratchathani, Nakhon Pathom and Songkhla.

Results for each site shown in this figure were obtained from all data of that site.

Additionally, this algorithm can be used to retrieve aerosol optical depth from satellite data only under clear sky condition. However, thin clouds such as cirrus are still difficult to identify through the visible data. The cloud screening problem is likely to contribute significantly to the error of AOD retrievals. The uncertainties of cloud screening and the mismatch of aerosol model are therefore the challenging problems to solve. For future development, cloud screening method should be further developed using a combination of visible and infrared satellite data. In addition, more accurate information on aerosols should be used for generating the LUT. 


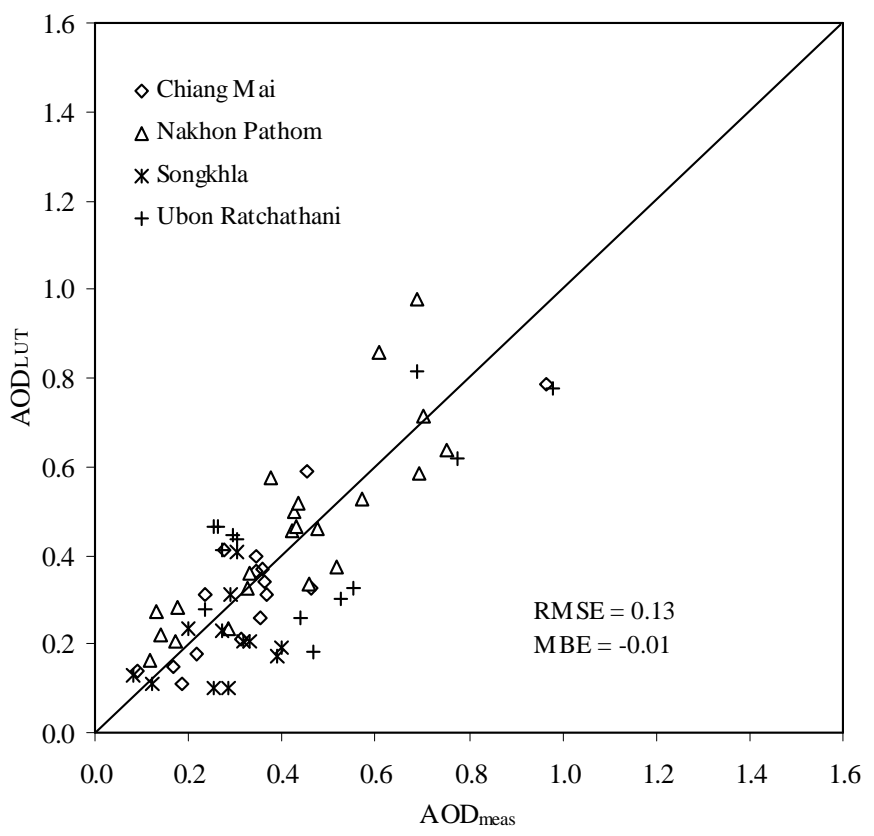

Fig. 7: Comparison between the monthly averaged aerosol optical depths derived from the algorithm and the AERONET measurements on clear sky periods.

\section{Conclusions}

An algorithm for the retrievals of aerosol optical depth from geostationary satellite has been developed by using a look-up table (LUT) approach. The LUT which incorporates a combination of atmospheric parameters were created using the $6 \mathrm{~S}$ radiative transfer code. The satellite visible data were used as the main input of the algorithm. The method for identifying clear sky pixels was also proposed. The comparison between monthly average aerosol optical depth obtained from the algorithm and the measurements showed a reasonable agreement.

\section{Acknowledgements}

The authors would like to thank Thailand Research Fund for the financial support to this research work. The authors also would like to thank Dr. Brent Holben for the permission to use the AERONET data and to Dr. David Giles for the arrangement and processing of the sunphotometer data. 


\section{REFERENCES}

[1] Breon F., Tanre D., and Generoso S., Aerosol effect on cloud droplet size monitored from satellite, Science, 295, pp. 834-838, 2002.

[2] Charlson R. J., Schwartz S. E., Hales J. M., Cess D., Coakley J. A., Hansen J. E., and Hofmann D. J., Climate forcing by anthropogenic aerosols, Science, 255, pp. 423-430, 1992.

[3] Crutzen P. J. and Andreae M. O., Biomass Burning in the Tropics: Impact on atmospheric chemistry and biogeochemical cycle, Science, 250, pp. 1669-1678, 1990.

[4] Deuzé J. L., Goloub P., Herman M., Marchand A., Perry G., Susana S., and Tanré D., Estimate of the aerosol properties over the ocean with POLDER, Journal of Geophysical Research, 105(D12), pp. 15,329-15,346, 2000.

[5] Dubovik O., Smirnov A., Holben B. N., King M. D., Kaufman Y. J., Eck T. F. and Slutsker I., Accuracy assessments of aerosol optical properties retrieved from Aerosol Robotic Network (AERONET) sun and sky radiance measurements, Journal of Geophysical Research, 105(D8), pp. 9791-9806, 2000.

[6] Dubovik O., Holben B. N., Eck T. F., Smirnov A., Kaufman Y. J., King M. D., Tanre D. and Slutsker I., Variability of absorption and optical propertyes of key aerosol types observed in worldwide locations, Journal of the Atmospheric Sciences, 59, pp. 519-608, 2002.

[7] Hansen J., Sato M., Ruedy R., Lacis A. and Oinas V., Global warming in the twenty-first century: An alternative scenario, Proc. Natl. Acad. Sci. U.S.A., 97, pp. 9875-9880, 2000.

[8] Hoyningen-Huene W., Schmidt T., Schienbein S., Kee C.A. and Tick L. J., Climate relevant aerosol parameters of South-East Asian forest fire haze, Atmospheric Environment, 33, pp. 3183-3190, 1999.

[9] Iqbal M., An Introduction to Solar Radiation, Academic, New York, 1983.

[10] Janjai S., Suntaropas S. and Nunez M., Investigation of aerosol optical properties in Bangkok and suburbs, Theoretical and Applied Climatology, 96, pp. 221-233, 2009.

[11] Janjai S., Wanvong W., Laksanaboonsong J., The determination of surface albedo of Thailand using satellite data, In Proceeding of the second Joint International Conference on Sustainable Energy and Environment (SEE2006) Bangkok, Thailand, pp. 156-161, 2006.

[12] Janjai S., Laksanaboonsong J., Nunez M. and Thongsathitya A., Development of a method generating operational solar radiation maps from satellite data for a tropical environment, Solar Energy, 78, pp.739-751, 2005. 
[13] Kaufman Y. J., Tanre' D., Remer L., Vermote E. F., Chu D. A. and Holben B. N., Operational remote sensing of tropospheric aerosol over the land from EOS-MODIS. Journal of Geophysical Research, 102, pp. 17,051-17,068, 1997.

[14] Knapp K. R., Vonder Haar T. H., and Kaufman Y. J, Aerosol optical depth retrieval from GOES-8: Uncertainty study and retrieval validation over South America, Journal of Geophysical Research, 107, 10.1029/2001JD000505, 2002.

[15] Knapp K. R., Frouin R., Kondragunta S. and Prados A., Toward aerosol optical depth retrievals over land from GOES visible radiances: determining surface reflectance. International Journal of Remote Sensing, 26(18), pp. 4097-4116, 2005.

[16] Li Z. Q., Xia X. A., Cribb M., Mi W., Holben B., Wang P., Chen H., Tsay S. C., Eck T. F., Zhao F., Dutton E. G. and Dickerson R. R., Aerosol Optical Properties and their Radiative Effects in Northern China, Journal of Geophysical Research, 112, D22S01. doi:10.1029/2006JD007382, 2007.

[17] Lohmann U. and Feichter J., Global indirect aerosol effects: a review, Atmospheric Chemistry and Physics, 5, pp. 715-737, 2005.

[18] Nakajima T., Sekiguchi M., Takemura T., Uno I., Higurashi A., Kim D. H., Sohn B. J., Oh S. N., Nakajima T. Y., Ohta S., Okada I., Takamura T. and Kawamoto K., Significance of direct and indirect radiative forcings of aerosols in the East China Sea region, Journal of Geophysical Research, 108(D23), 8658, doi: 10.1029/2002JD003261, 2003.

[19] Nunez M., The development of a satellite-based insolation model for the tropical western Pacific ocean, International Journal of Climatology, 13, pp. 607-627, 1993.

[20] Tanré D., Kaufman Y. J., Herman M. and Mattoo S., Remote sensing of aerosol properties over oceans using the MODIS/EOS spectral radiances, Journal of Geophysical Research, 102 (14), pp. 16,971-16,988, 1997.

[21] Torres O., Bhartia P. K., Herman J. R., Sinyuk A., Ginoux P. and Holben B., A longterm record of aerosol optical depth from TOMS observations and comparison to AERONET measurements, Journal of Atmospheric Sciences, 59(3), pp. 398-413, 2002,.

[22] Vermote E. F., Tanré D., Deuzé J. L., Herman M. and Morcrette J. J., Second simulation of the satellite signal in the solar spectrum, 6S: an overview, IEEE Transactions on Geoscience \& Remote Sensing, 35, pp. 675-686, 1997.

[23] Xie J. and Xia X., Long-term trend in aerosol optical depth from 1980 to 2001 in north China, Particuology, 6(2), pp. 106-111, 2008.

[24] Yu X., Cheng T., Chen J. and Liu Y, Climatology of aerosol radiative properties in northern China, Atmospheric Research, 84, pp. 132-141, 2007.

[25] Zhang X. Y., Arimoto R. and An Z. S., Dust emission from Chinese desert sources linked to variations in atmospheric circulation, Journal of Geophysical Research, 102(D23), pp. 28,041-28,047, 1997. 